\title{
Pengaruh Beban Kerja Terhadap Kepuasan Kerja Perawat Dengan Mediasi Stress Kerja
}

\author{
Laily Nurida Safitri, Mardi Astutik \\ STIE PGRI Dewantara Jombang
}

Korespondensi : nisa.camelia@yahoo.com

\begin{abstract}
Abstrak
Penelitian ini bertujuan untuk mengetahui pengaruh Beban Kerja terhadap Kepuasan Kerja melalui Stress Kerja baik secara langsung maupun tidak langsung pada perawat Rumah Sakit Unipdu Medika Jombang. Penelitian ini termasuk penelitian kuantitatif dengan menggunakan metode survey. Sampel dalam penelitian ini adalah seluruh perawat di Rumah Sakit Unipdu Medika Jombang yang berjumlah 38 orang. Pengumpulan data dengan observasi, wawancara, kuesioner dan dokumentasi. Sedangkan analisis data dilakukan dengan menggunakan analisis regresi berganda, analisis path dan uji sobel. Hasil penelitian ini menunjukkan bahwa : (1) Beban Kerja berpengaruh negatif dan signifikan terhadap Kepuasan Kerja Perawat di Rumah Sakit Unipdu Medika Jombang (2) Beban Kerja berpengaruh positif dan signifikan terhadap Stress Kerja Perawat di Rumah Sakit Unipdu Medika Jombang (3) Stress Kerja berpengaruh negatif dan signifikan terhadap Kepuasan Kerja Perawat di Rumah Sakit Unipdu Medika Jombang (4) Stress Kerja memediasi secara parsial antara Beban Kerja terhadap Kepuasan Kerja Perawat di Rumah Sakit Unipdu Medika Jombang.
\end{abstract}

Kata Kunci : Beban Kerja, Stress Kerja, Kepuasan Kerja.

\begin{abstract}
This study aims to determine the effect of Workload on Job Satisfaction through Job Stress both directly and indirectly to nurses at the Unipdu Medika Hospital in Jombang. This research includes quantitative research using survey methods. The sample in this study were all nurses at Unipdu Medika Jombang Hospital, amounting to 38 people. Data collection by observation, interviews, questionnaires and documentation. While data analysis was carried out using multiple regression analysis, path analysis and sobel test. The results of this study indicate that: (1) Workload has a negative and significant effect on Nurse Job Satisfaction at Unipdu Medika Jombang Hospital (2) Workload has a positive and significant effect on Nurse Job Stress at Unipdu Medika Jombang Hospital (3) Influential Work Stress negative and significant for Nurse Job Satisfaction at Unipdu Medika Jombang Hospital (4) Work Stress mediates partial between the Workload on Nurse Job Satisfaction in Unipdu Medika Jombang Hospital.

Keywords: Workload, Job Stress, Job Satisfaction.
\end{abstract}

\section{A. PENDAHULUAN}

Rumah sakit merupakan salah satu bentuk organisasi yang bergerak dibidang jasa pelayanan kesehatan. Pelayanan kesehatan pada rumah sakit merupakan salah satu pelayanan yang sangat penting, terutama pelayanan keperawatan secara profesional. Profesi perawat memiliki peran utama dalam kontak dengan pasien disebuah rumah sakit. Mayoritas tindakan medis yang diberikan kepada pasien dilakukan seluruhnya oleh perawat. Baumann (2007) menyatakan bahwa sumber daya manusia perawat merupakan faktor terpenting dalam pelayanan rumah sakit, bahkan hampir $80 \%$ pelayanan kesehatan diberikan oleh perawat.

Ada berbagai usaha untuk meningkatkan kepuasan kerja karyawan dalam hal ini adalah perawat yaitu dengan memperhatikan budaya organisasi (Bey, M. T., \& Dewi, R. C. K., 2018), intensif (Nurali, N, 2018) serta beban kerjanya. Menurut Rivai (2011) Beban kerja adalah tuntutan pekerjaan yang dilaksanakan sehari-hari dan dianggap 
sebagai beban. Saat menghadapi tugas, seorang perawat diharapkan dapat menyelesaikan tugas tersebut pada waktu tertentu. Namun pada kenyataannya beban kerja perawat banyak yang tidak sesuai dengan kemampuan yang dimiliki.

Selain beban kerja, faktor lain yang harus diperhatikan untuk mencapai kepuasan kerja adalah stress kerja. Pada dasarnya profesi perawat adalah profesi yang rentan stress. Baumann (2007) juga mengatakan bahwa 50,9\% perawat Indonesia diketahui mengalami stress kerja yang ditandai dengan sering merasa pusing, kurang istirahat akibat beban kerja yang terlalu banyak serta penghasilan yang rendah. Pertama, profesi perawat memiliki tugas dan tanggung jawab yang tinggi terhadap keselamatan nyawa manusia. Kedua, profesi ini menerapkan sistem kerja rotasi (shift). Rice (2005) menyebutkan bahwa kerja shift merupakan stressor yang dapat menyebabkan stress kerja bagi karyawan. Perawat yang bekerja diluar jam normal adalah mereka yang mendapat kerja shift malam. Hal ini bisa menyebabkan gangguan pada kesehatan perawat.

Fenomena menurunnya kepuasan kerja di Rumah Sakit Unipdu Medika Jombang diduga disebabkan oleh beban kerja. Berdasarkan informasi dari Kabag Personalia yang menunjukkan jumlah pasien semakin meningkat perbulannya dibandingkan dengan jumlah perawat yang tetap selama tahun 2017 yakni 38 orang. Beban kerja yang banyak akan menimbulkan kesalahan akibat ketidakmampuan mengatasi tuntutan kerja. Karena dari data rekapitulasi, pasien terbanyak ada diruang IGD (Instalasi Gawat Darurat). Pasien yang masuk dijalur IGD adalah pasien yang mengalami keadaan darurat dan harus segera mendapatkan pertolongan pertama. Hal tersebut membutuhkan tanggung jawab yang besar terutama keselamatan pasien dan konsentrasi yang tinggi saat melakukan pekerjaan.

Tingginya beban kerja diduga menjadi sebab meningkatnya stress kerja di Rumah Sakit Unipdu Medika Jombang. Hal ini terlihat pada mereka yang lebih banyak diam (tidak komunikatif), tampak kelelahan, sering pusing kepala, dan mudah marah (emosi). Sehingga dampak yang ditimbulkan dari stress kerja yaitu mereka sering datang terlambat saat bekerja, dan dari data kehadiran banyak perawat yang izin atau tidak masuk kerja karena sakit. Akibat stress kerja yang tinggi dapat membuat kesehatan karyawan terganggu yang kemudian menyebabkan banyaknya karyawan tidak masuk kerja. Jadi karena beban kerja yang banyak tersebut bisa membuat seseorang menjadi stress. Sesuai dengan penelitian Purboningrat Yo dan Surya (2015), didapati bahwa beban kerja berpengaruh positif terhadap stress kerja, yaitu bila beban kerja karyawan meningkat maka stress kerja karyawan juga akan meningkat.

Dampak dari beban kerja dan stress kerja dapat menurunkan kepuasan kerja seseorang. Sesuai penelitian yang dilakukan Chuzaeni (2017) didapati beban kerja dan stress kerja berpengaruh negatif terhadap kepuasan kerja, dengan artian apabila beban kerja dan stress kerja meningkat maka akan menyebabkan penurunan kepuasan kerja. Kepuasan berkurang juga ditandai dengan ketidakpuasan terhadap kompensasi yang belum sesuai dengan Upah Minimum Kabupaten (UMK). Dikarenakan semakin naiknya harga kebutuhan pokok, ditambah mayoritas perawat sudah berkeluarga membuat mereka cemas dan memikirkan apakah dengan kompensasi sedemikian akan cukup untuk memenuhi kebutuhan keluarganya.

Beban kerja tidak hanya berpengaruh secara langsung terhadap kepuasan kerja karyawan, tetapi dapat juga berpengaruh tidak langsung melalui mediasi stress kerja. Hal ini dibuktikan dengan penelitiannya Susanti, et al (2015) bahwa beban kerja tidak berpengaruh signifikan terhadap kepuasan kerja, maka dari itu harus menggunakan 
mediasi stress kerja agar hasilnya signifikan, dan hasilnya stress kerja berperan sebagai full mediasi antara beban kerja terhadap kepuasan kerja. Sehingga diartikan beban kerja yang berlebihan pada individu dapat menyebabkan stress kerja pada pekerjaannya. Akibatnya yang terjadi yaitu apabila stress kerja terlalu tinggi akan menyebabkan penurunan kepuasan kerja.

Rumusan masalah dalam penelitian ini adalah: 1) Apakah terdapat pengaruh Beban Kerja terhadap Kepuasan Kerja Perawat di Rumah Sakit Unipdu Medika Jombang? 2) Apakah terdapat pengaruh Beban Kerja terhadap Stress Kerja Perawat di Rumah Sakit Unipdu Medika Jombang? 3) Apakah terdapat pengaruh Stress Kerja terhadap Kepuasan Kerja Perawat di Rumah Sakit Unipdu Medika Jombang? 4) Apakah terdapat pengaruh Beban Kerja terhadap Kepuasan Kerja Perawat melalui Stress Kerja sebagai variabel mediasi di Rumah Sakit Unipdu Medika Jombang?

\section{B. KAJIAN PUSTAKA}

\section{Pengertian Beban Kerja}

Menurut Marquis dan Houston (2000), beban kerja perawat adalah seluruh kegiatan atau aktivitas yang dilakukan oleh seorang perawat selama bertugas disuatu unit pelayanan keperawatan. Menurut Menteri Pendayagunaan Aparatur Negara (Menpan,2008), Beban kerja adalah sekumpulan atau sejumlah kegiatan yang harus diselesaikan oleh suatu unit organisasi atau pemegang jabatan dalam jangka waktu tertentu. Menurut Meshkati dan Hariyati (2011) dalam Saefullah (2017) Beban Kerja adalah suatu perbedaan antara kapasitas atau kemampuan pekerja dengan tuntutan pekerjaan yang harus dihadapi. Mengingat kerja manusia masing-masing mempunyai tingkat pembebanan yang berbeda-beda. Tingkat beban yang terlalu tinggi memungkinkan pemakaian energi yang berlebihan dan terjadi overstress, sebaliknya tingkat beban yang terlalu rendah memungkinkan rasa bosan dan kejenuhan (understress).

Indikator beban kerja yang digunakan menurut Tarwaka (2011) dalam Febriani (2017) dikategorikan dalam dimensi, antara lain :

a. Beban waktu (time load), menunjukkan jumlah waktu yang tersedia dalam perencanaan, pelaksanaan dan monitoring tugas atau kerja yang meliputi standar waktu pelaksanaan kerja, dan waktu istirahat.

b. Beban usaha mental (mental effort load), banyaknya usaha mental atau tugas-tugas yang harus dikerjakan, volume (ukuran) pekerjaan, tanggung jawab pekerjaan yang besar, tingkat kesulitan pekerjaan yang dihadapi, dan tingkat resiko pekerjaan.

c. Beban tekanan psikologis (psychological stress load), yang menunjukkan kebingungan, frustasi dan konsentrasi dalam melaksanakan pekerjaan (fokus/tidak fokus).

\section{Pengertian Stress Kerja}

Menurut Robbins (2007) stress kerja ialah kondisi ketegangan yang mempengaruhi emosi, jalan pikiran dan kondisi fisik seseorang. Menurut Rivai (2009)) stress kerja ialah suatu keadaan yang menciptakan ketidakseimbangan fisik dan psikis yang berpengaruh pada emosi, proses berpikir, dan kondisi seseorang. Menurut Mangkunegara (2017) stress kerja ialah perasaan tertekan dalam menghadapi pekerjaan yang dialami karyawan. Stress yang tidak diatasi dengan baik akan berakibat pada ketidakmampuan seseorang untuk berinteraksi secara positif dengan lingkungannya, baik lingkungan internal maupun lingkungan eksternal. 
Indikator Stress Kerja menurut Robbins (2008) dibagi menjadi tiga aspek, yaitu: 1) Indikator pada psikologis, 2) Indikator pada fisik, dan 3) Indikator pada perilaku.

\section{Pengertian Kepuasan Kerja}

Menurut Milton dalam Nimran \& Amirullah (2015) Kepuasan Kerja merupakan keadaan emosional positif atau menyenangkan yang dihasilkan dari penilaian karyawan berdasarkan pengalaman kerjanya. Milton juga mengatakan reaksi positif karyawan terhadap pekerjaannya tergantung pada taraf pemenuhan kebutuhan fisik dan psikologis karyawan tersebut oleh pekerjaannya. Kesenjangan antara yang diterima karyawan dari pekerjaannya dengan yang diharapkannya menjadi dasar munculnya kepuasan kerja. Sedangkan menurut Handoko (2008) kepuasan kerja adalah keadaan emosional yang menyenangkan atau tidak menyenangkan para karyawan dalam memandang pekerjaan mereka. Kepuasan kerja mencerminkan perasaaan puas seseorang terhadap pekerjaannya. Hal ini dimunculkan dalam sikap positif karyawan terhadap pekerjaan dan segala sesuatu yang dihadapi di lingkungan kerjanya.

Indikator kepuasan kerja menurut Smith, Kendall, dan Hulin dalam Nimran \& Amirullah (2015), menyebutkan lima indikator meliputi: 1) Kepuasan terhadap pekerjaan itu sendiri, 2) Kepuasan terhadap pembayaran/gaji, 3) Kepuasan terhadap promosi, 4) Kepuasan terhadap supervisi/pimpinan, 5) Kepuasan terhadap teman kerja.

Kepuasan kerja dapat dipengaruhi oleh beban kerja sehari-hari, karyawan lebih merasa puas ketika mereka diberikan beban yang rendah atau sedang. Karena beban kerja yang berat, besar kemungkinan orang tersebut akan merasakan ketidakpuasan terhadap pekerjaannya. Seperti yang dikemukakan Spector (1997) yang mengatakan tuntutan pekerjaan yang berlebihan sering menyebabkan ketidakpuasan kerja, stress dan kelelahan yang semuanya dapat mempengaruhi absensi. Sehingga bisa disimpulkan banyak yang meneliti bahwa beban kerja berdampak negatif terhadap kepuasan kerja.

Berbagai jenis tugas dalam pekerjaan merupakan kewajiban yang harus dilaksanakan oleh seseorang. Namun dalam kenyataannya tidak menutup kemungkinan tugas-tugas tersebut menyebabkan munculnya stress kerja bagi karyawan. Beban kerja merupakan faktor penyebab stress kerja, sehingga beban kerja yang tinggi pasti akan menimbulkan stress kerja. Menurut Riggio (2000) menyatakan beban kerja adalah tugas-tugas pekerjaan yang menjadi sumber stress seperti pekerjaan yang mengharuskan bekerja lebih cepat, menghasilkan sesuatu dan konsentrasi dari stress kerja. Senada dengan Munandar (2001), berpendapat bahwa tidak kesesuaian antara tuntutan tugas dengan kapasitas yang dimiliki, maka akan menimbulkan stress kerja. Sehingga banyak penelitian yang menemukan bahwa beban kerja bersifat positif terhadap stress kerja.

Stress kerja dan kepuasan kerja saling berhubungan. Seperti yang dikemukakan Robbins (2003), bahwa salah satu dampak stress secara psikologis dapat menurunkan kepuasan kerja. Kepuasan dalam bekerja dapat ditemukan apabila ada keseimbangan antara apa yang diharapkan dan apa yang diterimanya dalam bekerja. Hal ini berarti bahwa stress kerja berdampak negatif terhadap kepuasan kerja karyawan. Yang sering terjadi adalah tekanan pada kondisi kerja dan rendahnya kompensasi dapat menimbulkan stress kerja dan penurunan kepuasan kerja. Sesuai dengan pendapat Wibowo (2011) dalam Putu dan Ida (2015) bahwa stress yang terjadi ditempat kerja menyebabkan : rendahnya kualitas pelayanan, pergantian staf yang tinggi, reputasi dan citra perusahaan menjadi buruk, dan ketidakpuasan kerja.

Beban kerja dan stress kerja merupakan salah satu faktor yang menyebabkan menurunnya kepuasan kerja. Beban kerja dapat berpengaruh secara langsung maupun 
tidak langsung terhadap menurunnya kepuasan kerja, secara tidak langsungnya yaitu dengan melalui mediasi stress kerja. Menurut Patricia, et al (2016) jika tuntutan pekerjaan lebih tinggi daripada kemampuan bekerja, akan memunculkan stress kerja. Jadi disisi lain stress kerja dapat terjadi akibat dampak dari beban kerja yang tinggi, hal inilah yang menyebabkan kepuasan kerja menurun. Senada dengan pendapat Mudayana dalam Hannani (2016) bahwa beban kerja karyawan perlu diperhatikan agar tidak terjadi over yang dapat menimbulkan stress kerja yang dapat berakibat pada menurunnya kepuasan kerja. Sehingga bisa disimpulkan banyak yang meneliti bahwa stress kerja memediasi penuh antara beban kerja terhadap kepuasan.

\section{Kerangka Konseptual}

Dari kajian pustaka serta penelitian terdahulu yang telah dilakukan maka kerangka konseptual dalam penelitian ini adalah sebagai berikut:

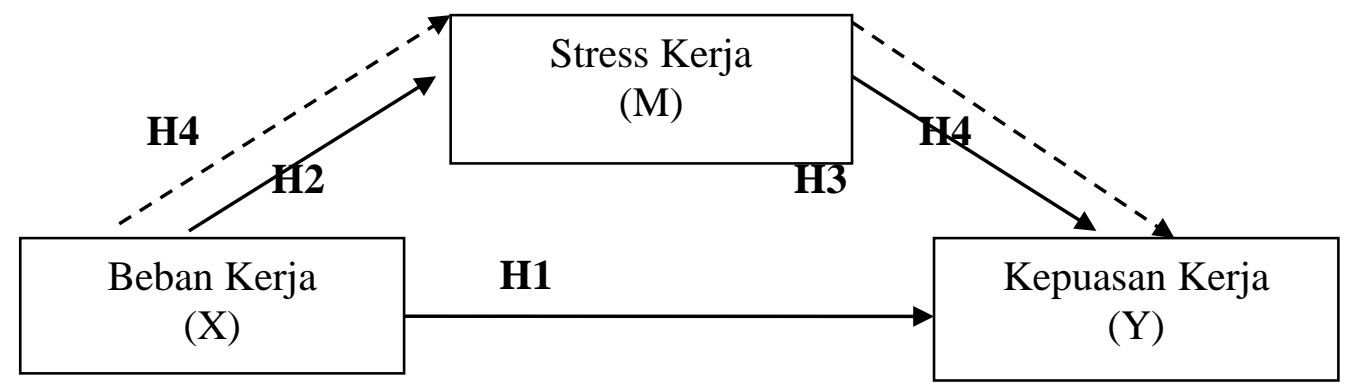

Gambar 1: Kerangka Konseptual

Dari gambar tersebut diatas, maka hipotesis yang berlaku pada penelitian ini adalah:

H1 : Semakin tinggi Beban Kerja, maka Kepuasan Kerja Perawat di Rumah Sakit Unipdu Medika Jombang akan semakin menurun.

H2 : Semakin tinggi Beban Kerja, maka Stress Kerja Perawat di Rumah Sakit Unipdu Medika Jombang akan semakin meningkat.

H3 : Semakin tinggi Stress Kerja, maka Kepuasan Kerja Perawat di Rumah Sakit Unipdu Medika Jombang akan semakin menurun.

H4 : Stress Kerja memediasi hubungan Beban Kerja terhadap Kepuasan Kerja Perawat di Rumah Sakit Unipdu Medika Jombang

\section{METODE PENELITIAN}

\section{Rancangan Penelitian}

Desain penelitian ini menggunakan metode penelitian kuantitatif dengan menggunakan metode survey. Metode pengumpulan data dengan cara observasi, wawancara, kuesioner, dan dokumentasi. Skala pengukuran yang digunakan adalah skala likert.

Populasi dalam penelitian ini adalah keseluruhan Perawat Rumah Sakit Unipdu Medika Jombang yang berjumlah 38 orang. Melihat dari jumlah populasi, teknik sampling yang digunakan dalam penelitian ini adalah Teknik Sampling Jenuh. Sehingga sampel responden yang akan diteliti yaitu tetap berjumlah 38 orang.

\section{Uji Instrument}

Menggunakan uji instrumen yaitu uji validitas dan uji reliabilitas dengan teknik analisis deskriptif, analisis regresi berganda dan teknik analisis jalur (path analysis). Serta menggunakan uji hipotesis yaitu uji $\mathrm{T}$, koefisien determinasi $\left(\mathrm{R}^{2}\right)$ dan Sobel Test dengan bantuan program aplikasi SPSS 21. 


\section{HASIL PENELITIAN DAN PEMBAHASAN \\ 1. Uji Validitas dan Uji Reliabilitas}

Tabel1: Hasil Uji Validitas

\begin{tabular}{|c|c|c|c|c|}
\hline Variabel & Item & r hitung & r tabel & Keterangan \\
\hline \multirow{6}{*}{ Beban Kerja (X) } & 1 & 0,617 & 0,361 & Valid \\
\hline & 2 & 0,635 & 0,361 & Valid \\
\hline & 3 & 0,745 & 0,361 & Valid \\
\hline & 4 & 0,747 & 0,361 & Valid \\
\hline & 5 & 0,592 & 0,361 & Valid \\
\hline & 6 & 0,796 & 0,361 & Valid \\
\hline \multirow{8}{*}{ Stress Kerja (M) } & 1 & 0,640 & 0,361 & Valid \\
\hline & 2 & 0,803 & 0,361 & Valid \\
\hline & 3 & 0,791 & 0,361 & Valid \\
\hline & 4 & 0,574 & 0,361 & Valid \\
\hline & 5 & 0,640 & 0,361 & Valid \\
\hline & 6 & 0,803 & 0,361 & Valid \\
\hline & 7 & 0,777 & 0,361 & Valid \\
\hline & 8 & 0,534 & 0,361 & Valid \\
\hline \multirow{5}{*}{ Kepuasan Kerja (Y) } & 1 & 0,700 & 0,361 & Valid \\
\hline & 2 & 0,708 & 0,361 & Valid \\
\hline & 3 & 0,707 & 0,361 & Valid \\
\hline & 4 & 0,395 & 0,361 & Valid \\
\hline & 5 & 0,621 & 0,361 & Valid \\
\hline
\end{tabular}

Sumber : Data primer yang diolah, 2018

Dari tabel 1 (satu) diatas menunjukkan bahwa semua item pernyataan memiliki nilai korelasi berada diatas 0,361 , sehingga dapat disimpulkan bahwa semua item pernyataan dinyatakan valid dan dapat dijadikan alat ukur untuk diteliti.

Tabel 2: Hasil Uji Reliabilitas

\begin{tabular}{cccc}
\hline Variabel & Alpha & Koefisien Alpha & Keterangan \\
\hline Beban Kerja $(\mathrm{X})$ & 0,763 & 0,60 & Reliabel \\
\hline Stress Kerja $(\mathrm{M})$ & 0,836 & 0,60 & Reliabel \\
\hline Kepuasan Kerja (Y) & 0,626 & 0,60 & Reliabel \\
\hline
\end{tabular}

Sumber : Data primer yang diolah, 2018

Dari hasil uji reliabilitas tersebut menunjukkan bahwa semua variabel mempunyai koefisien alpha yang cukup besar yaitu diatas 0,60 sehingga dapat dikatakan semua konsep pengukur masing-masing variabel tersebut adalah reliabel dan layak digunakan sebagai alat ukur. 


\section{Pengujian Pengaruh Beban Kerja terhadap Stress Kerja}

Tabel 3: Regresi Linier Sederhana (X Terhadap M)

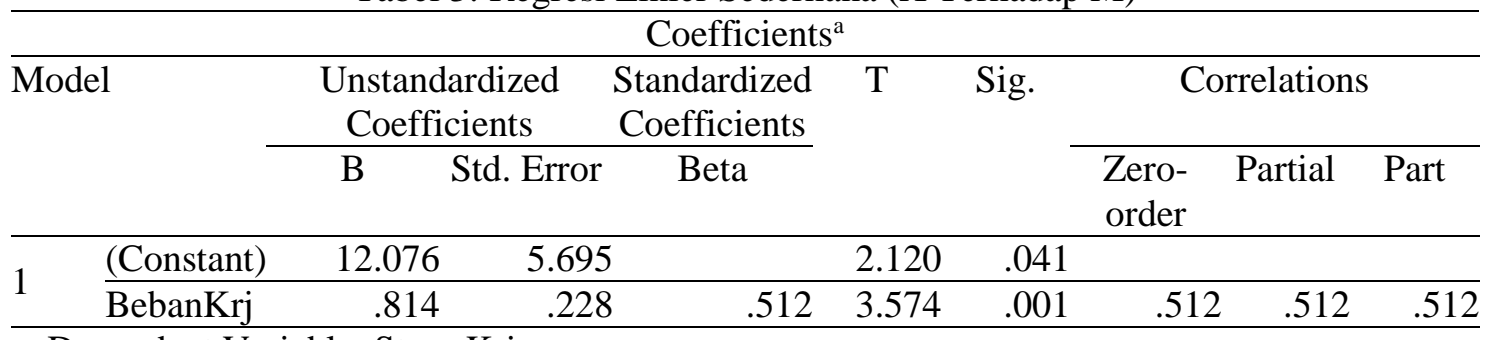

a. Dependent Variable: StressKrj

Sumber : Data primer diolah, 2018

Berdasarkan hasil analisis regresi diatas, diperoleh persamaan regresinya yaitu $\mathrm{M}=\mathbf{1 2 . 0 7 6}+\mathbf{0 , 8 1 4 \mathrm { X }}+\mathbf{e}_{1}$.

Sehingga diperoleh Beban Kerja (X) berpengaruh positif terhadap Stress Kerja (M) dengan koefisien regresi sebesar 0,814 yang artinya jika beban kerja perawat mengalami peningkatan, maka stress kerja juga akan meningkat.

Tabel 4: Koefisien Determinasi $\left(\mathrm{R}^{2}\right)$ X Terhadap $\mathrm{M}$

\begin{tabular}{|c|c|c|c|c|c|c|c|c|c|c|}
\hline \multicolumn{11}{|c|}{ Model Summary ${ }^{b}$} \\
\hline \multirow[t]{2}{*}{ Model } & \multirow[t]{2}{*}{$\mathrm{R}$} & \multirow{2}{*}{$\begin{array}{c}\mathrm{R} \\
\text { Square }\end{array}$} & \multirow{2}{*}{$\begin{array}{l}\text { Adjusted } \\
\text { R Square }\end{array}$} & Std. Error & \multicolumn{5}{|c|}{ Change Statistics } & \multirow{2}{*}{$\begin{array}{l}\text { Durbin- } \\
\text { Watson }\end{array}$} \\
\hline & & & & $\begin{array}{c}\text { of the } \\
\text { Estimate }\end{array}$ & $\begin{array}{c}\text { R Square } \\
\text { Change }\end{array}$ & $\begin{array}{c}\mathrm{F} \\
\text { Change }\end{array}$ & df1 & df2 & $\begin{array}{l}\text { Sig. F } \\
\text { Change }\end{array}$ & \\
\hline 1 & $.512^{\mathrm{a}}$ & .262 & .241 & 4.130 & .262 & 12.773 & & 36 & .001 & 1.198 \\
\hline
\end{tabular}

a. Predictors: (Constant), BebanKrj

b. Dependent Variable: StressKrj

Sumber : Data primer diolah, 2018

Berdasarkan tabel diatas, nilai koefisien determinasinya adalah sebesar 0,262. Hal ini berarti bahwa variabel Stress Kerja dapat dijelaskan oleh variabel Beban Kerja sebesar 26,2\% sedangkan sisanya sebesar 73,8\% dijelaskan oleh sebab lain diluar variabel beban kerja. Koefisien determinasi juga dapat digunakan untuk menghitung error, sehingga nilai error $1\left(\mathrm{e}_{1}\right)$ yaitu sebesar $\sqrt{1-R^{2}}=\sqrt{1-0,262}=\sqrt{0,738}=0,85$ (Marsono, 2014 : 14)

\section{Pengujian Pengaruh Beban Kerja dan Stress Kerja Terhadap Kepuasan Kerja}

Tabel 5: Regresi Linier Berganda (X dan M terhadap Y)

\begin{tabular}{|c|c|c|c|c|c|c|c|c|}
\hline \multirow{3}{*}{\multicolumn{2}{|c|}{ Model }} & \multicolumn{5}{|c|}{ Coefficients $^{\mathrm{a}}$} & \multirow{2}{*}{\multicolumn{2}{|c|}{ Correlations }} \\
\hline & & \multicolumn{2}{|c|}{$\begin{array}{l}\text { Unstandardized } \\
\text { Coefficients }\end{array}$} & \multirow{2}{*}{$\begin{array}{c}\begin{array}{c}\text { Standardized } \\
\text { Coefficients }\end{array} \\
\text { Beta }\end{array}$} & \multirow[t]{2}{*}{$\mathrm{T}$} & \multirow[t]{2}{*}{ Sig. } & & \\
\hline & & $\mathrm{B}$ & Std. Error & & & & \multirow[t]{2}{*}{$\begin{array}{l}\text { Zero- } \\
\text { order }\end{array}$} & \\
\hline \multirow{3}{*}{1} & $\begin{array}{l}\text { del } \\
\text { (Constant) } \\
\end{array}$ & 17.657 & 2.989 & & 5.908 & .000 & & \\
\hline & \multirow{2}{*}{ BebanKrj } & -.317 & .131 & -.386 & -2.419 & .021 & -.038 & -.331 \\
\hline & & -.352 & .082 & -.680 & -4.263 & .000 & -.483 & -.584 \\
\hline
\end{tabular}

a. Dependent Variable: KepuasanKrj

Sumber : SPSS 21, 2018 
Berdasarkan hasil regresi diatas, diperoleh persamaan regresinya yaitu $\mathbf{Y}=$ 17.657 - 0,317X - 0,352M + e2. Sehingga diperoleh variabel Beban Kerja (X) berpengaruh negatif terhadap Kepuasan Kerja (Y) dengan koefisien regresi sebesar 0,317 yang artinya jika beban kerja mengalami peningkatan, maka kepuasan kerja perawat justru mengalami penurunan. Sedangkan variabel Stress Kerja (M) berpengaruh negatif terhadap Kepuasan Kerja (Y) dengan koefisien regresi sebesar 0,352 yang artinya jika stress kerja mengalami peningkatan, maka kepuasan kerja perawat justru mengalami penurunan.

Nilai koefisien regresi untuk variabel Beban Kerja (X) terhadap Kepuasan Kerja (Y) menunjukkan hasil signifikansinya adalah 0,021 < 0,05. Hal ini berarti bahwa variabel Beban Kerja (X) berpengaruh signifikan terhadap Kepuasan Kerja (Y). Selanjutnya nilai regresi untuk variabel Stress Kerja (M) terhadap Kepuasan Kerja (Y) menunjukkan bahwa hasil signifikannya adalah $0,000<0,05$. Hal ini berarti bahwa variabel Stress Kerja (M) berpengaruh signifikan terhadap Kepuasan Kerja (Y). Adapun besarnya pengaruh beban kerja dan stress kerja terhadap kepuasan kerja yaitu :

Tabel 6: Koefisien Determinasi $\left(\mathrm{R}^{2}\right) \mathrm{X}$ dan $\mathrm{M}$ terhadap $\mathrm{Y}$

\begin{tabular}{|c|c|c|c|c|c|c|c|c|}
\hline & \multicolumn{7}{|c|}{ Model Summary ${ }^{\mathrm{b}}$} & \multirow{3}{*}{$\begin{array}{l}\text { Durbin- } \\
\text { Watson }\end{array}$} \\
\hline \multirow[t]{2}{*}{ Model } & $\mathrm{R}$ & $\mathrm{R}$ & Adjusted Std. Error & & Chang & Statistics & & \\
\hline & & Square & $\begin{array}{r}\text { R Square of the } \\
\text { Estimate }\end{array}$ & $\begin{array}{l}\text { R Square } \\
\text { Change }\end{array}$ & $\begin{array}{c}\mathrm{F} \\
\text { Change }\end{array}$ & df1 df2 & $\begin{array}{l}\text { Sig. F } \\
\text { Change }\end{array}$ & \\
\hline 1 & $.585^{\mathrm{a}}$ & .343 & 2.043 & .343 & 9.126 & 35 & .001 & 1.000 \\
\hline
\end{tabular}

a. Predictors: (Constant), StressKrj, BebanKrj

b. Dependent Variable: KepuasanKrj

Sumber : Data primer diolah, 2018

Berdasarkan tabel diatas, nilai koefisien determinasinya adalah sebesar 0,343. Hal ini berarti bahwa variabel Kepuasan Kerja dapat dijelaskan oleh variabel Beban Kerja dan Stress Kerja sebesar 34,3\% sedangkan sisanya sebesar 65,7\% dijelaskan oleh sebab lain diluar kedua variabel bebas tersebut. Koefisien determinasi juga dapat digunakan untuk menghitung error, sehingga nilai error $2\left(\mathrm{e}_{2}\right)$ yaitu sebesar $\sqrt{1-R^{2}}=\sqrt{1-0,343}$ $=\sqrt{0,657}=0,81($ Marsono, $2014: 14)$

\section{Pengujian Stress Kerja Memediasi Pengaruh Antara Beban Kerja Terhadap Kepuasan Kerja}

\section{a. Analisis Jalur (Path Analysis)}

Analisis jalur adalah analisis hasil lanjutan dari kedua model regresi untuk mencari nilai dari hipotesis 4 (H4). Hasil dari analisis jalur ini ditunjukkan dengan hasil diagram jalur sebagai berikut :

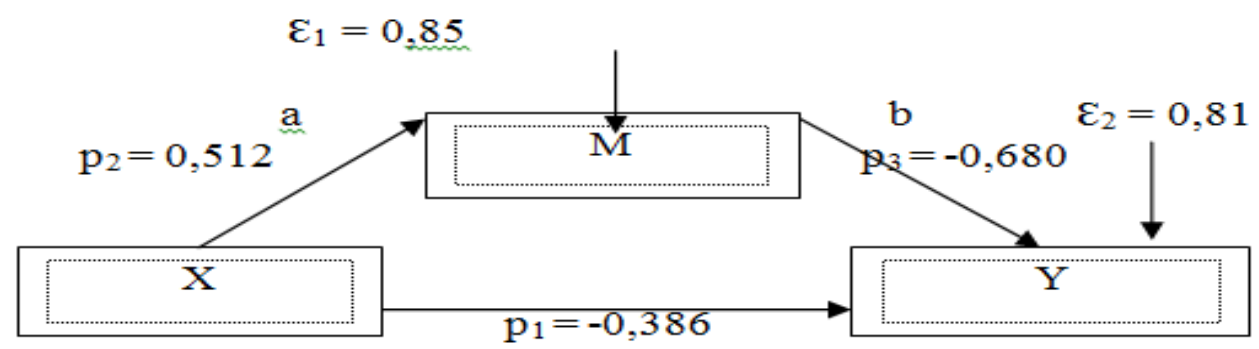

\section{Gambar 2: Hasil Diagram Jalur}

JMD: Jurnal Riset Manajemen Dan Bisnis Dewantara

Vol 2 No 1, Juni 2019

ejournal.stiedewantara.ac.id/index.php/JMD 
Berdasarkan hasil diagram jalur diatas, diketahui bahwa pengaruh langsung $\mathrm{X}$ ke Y sebesar -0,386, kemudian dilanjutkan dengan uji sobel untuk mengetahui seberapa besar Stress Kerja dalam memediasi hubungan antara Beban Kerja dengan Kepuasan Kerja.

\section{b. Uji i Sobel (Sobel Test)}

Dari data yang masuk, selanjutnya diolah menggunakan uji Sobel. Perhitungan dengan uji sobel menunjukkan nilai sobel test (z-value) sebesar -3.535 dengan p-value $0.000<$ alpha $(0,05)$, dan menunjukkan hasil bahwa penelitian ini terdapat pengaruh mediasi dengan tipe completely mediation. Kemudian disisi lain diketahui bahwa pengaruh tidak langsungnya sebesar $-0,348$ nilainya lebih kecil dibandingkan dengan pengaruh langsungnya sebesar -0,386. Sehingga disimpulkan bahwa Stress Kerja memediasi secara parsial hubungan antara Beban Kerja terhadap Kepuasan Kerja, yang artinya beban kerja dapat berpengaruh secara langsung terhadap kepuasan kerja, tanpa harus melalui mediasi stress kerja, dan juga beban kerja dapat berpengaruh terhadap kepuasan kerja melalui mediasi stress kerja. Sehingga disimpulkan bahwa hipotesis keempat (H4) dalam penelitian ini diterima.

\section{Pengaruh Beban Kerja Terhadap Kepuasan Kerja}

Berdasarkan hasil pengujian yang telah dilakukan menunjukkan adanya pengaruh beban kerja terhadap kepuasan kerja. Beban kerja yang berlebihan menyebabkan penurunan kepuasan kerja perawat di Rumah Sakit Unipdu Medika Jombang sehingga semakin banyak pekerjaan yang ditangani, membuat semakin rendah tingkat kepuasan kerja perawat. Dalam persepsi karyawan, beban kerja adalah penilaian individu atas sejumlah tuntutan tugas yang membutuhkan kekuatan dan konsentrasi yang kuat. Sedangkan kepuasan ditemukan apabila ada keseimbangan antara apa yang diharapkannya sesuai dengan apa yang diterimanya dalam bekerja.

Dari penelitian diketahui bahwa beban kerja yang diberikan perusahaan dirasa masih tinggi, sehingga perawat mengalami penurunan kepuasan kerja. Hal ini terlihat bahwa waktu penyelesaian tugas, waktu istirahat, tingkat kesulitan, resiko pekerjaan masih tinggi dan belum sesuai dengan harapan perawat. Kepuasan kerja menurun juga disebabkan karena beban kerja yang ditugaskan belum sesuai dengan upah yang diberikan. Sesuai dengan wawancara awal bahwa kepuasan menurun disebabkan karena kompensasi belum sesuai dengan tuntutan kerja yang diberikan perusahaan.

Hasil penelitian memperkuat penelitian sebelumnya yang dilakukan oleh Karina Anggraeni (2018) yang membuktikan bahwa beban kerja berpengaruh negatif dan signifikan terhadap kepuasan kerja karyawan di CV. Bartec Utama Mandiri Semarang.

\section{Pengaruh Beban Kerja Terhadap Stress Kerja}

Berdasarkan hasil pengujian yang telah dilakukan menunjukkan adanya pengaruh beban kerja terhadap stress kerja. Beban kerja yang berlebihan menyebabkan peningkatan pada stress kerja perawat di Rumah Sakit Unipdu Medika Jombang, sehingga semakin banyak pekerjaan yang harus diselesaikan, tidak dipungkiri akan semakin tinggi pula stress kerja perawat, karena stress kerja dapat timbul akibat tekanan yang bersumber dari ketidaksesuaian antara kemampuan seorang individu dengan banyaknya pekerjaan yang ditangani. Beban kerja tidak akan menimbulkan stress kerja, apabila beban kerja yang ditangani seimbang dengan jumlah perawat dan pembagian tugas yang sesuai. 
Dari penelitian diketahui bahwa Beban kerja perawat Rumah Sakit Unipdu Medika Jombang dirasa masih tinggi, sehingga perawat mengalami peningkatan stress kerja. Hal ini terlihat dari perawat yang menjadi mudah marah, sering kelelahan, sering pusing, dan mengalami gangguan tidur.

Hasil penelitian ini memperkuat penelitian sebelumnya yang dilakukan oleh Purboningrat Yo dan Surya (2015) yang membuktikan bahwa beban kerja berpengaruh positif dan signifikan terhadap stress kerja karyawan di PT. Lianinti Abadi Denpasar Bali.

\section{Pengaruh Stress Kerja Terhadap Kepuasan Kerja}

Berdasarkan hasil pengujian yang telah dilakukan menunjukkan adanya pengaruh stress kerja terhadap kepuasan kerja. Stress kerja yang tinggi menyebabkan penurunan kepuasan kerja perawat di Rumah Sakit Unipdu Medika Jombang, sehingga semakin banyak mereka mengalami stress, semakin rendah kepuasan kerja mereka. Hal ini menunjukkan bahwa stress kerja dapat berdampak pada penurunan fisik karyawan. Secara sederhana berarti bahwa stress berpotensi mengganggu pelaksanaan kerja perawat. Stress yang tidak dapat diatasi dapat berpengaruh pada ketidakpuasan kerja.

Dari penelitian diketahui bahwa stress kerja perawat dirasakan cukup namun cenderung tinggi. Hal ini terlihat dari perawat yang menjadi mudah marah, sering kelelahan, sering pusing, dan mengalami gangguan tidur. Apabila hal tersebut tidak segera ditangani, maka dapat membuat fisik perawat sakit sehingga akan mempengaruhi tingkat absensi yang semakin tinggi. Akan tetapi masih ada beberapa perawat yang tidak menganggap bahwa stress kerja sebagai sesuatu yang menghambat pekerjaan mereka, namun lebih menganggap bahwa stress kerja sebagai sesuatu yang sifatnya membantu mereka untuk bekerja lebih keras. Hal ini dikaitkan dengan banyaknya yang menjawab pernyataan "netral".

Kemudian kaitan lainnya stress kerja dengan kepuasan kerja adalah terdapat pada skor terendah kepuasan kerja yaitu pembayaran/gaji belum sesuai dengan Upah Minimum Regional (UMR). Sehingga disimpulkan stress kerja dapat ditimbulkan akibat kompensasi yang minim. Hal ini sesuai dengan wawancara awal bahwa dengan kompensasi yang minim ditambah mayoritas sudah berumah tangga dan naiknya kebutuhan pokok dapat menyebabkan stress kerja dan kepuasan kerja perawat menurun.

Hasil penelitian ini mendukung penelitian dari Nelfiandra Susanti, dkk (2015) yang membuktikan bahwa stress kerja berpengaruh negatif dan signifikan terhadap kepuasan kerja Guru SDN di Kecamatan Pasaman Kabupaten Pasaman Barat.

\section{Pengaruh Beban Kerja Terhadap Kepuasan Kerja Dengan Stress Kerja Sebagai Variabel Mediasi}

Hasil penelitian yang telah dilakukan, menunjukkan bahwa beban kerja berpengaruh terhadap kepuasan kerja dengan dua jalan yaitu beban dapat berpengaruh secara langsung terhadap kepuasan kerja perawat dan dapat berpengaruh dengan melalui mediasi Stress kerja. Artinya semakin tinggi beban kerja akan mengakibatkan semakin tinggi stress kerja perawat, dengan tingginya stress kerja perawat maka dapat membuat semakin menurunnya kepuasan kerja perawat di Rumah Sakit Unipdu Medika Jombang.

Hasil penelitian ini memperkuat penelitian dari Purboningrat Yo dan Surya (2015) yang membuktikan bahwa stress kerja berperan sebagai mediasi hubungan 
antara beban kerja terhadap kepuasan kerja karyawan di PT. Lianinti Abadi Denpasar Bali.

\section{E. PENUTUP}

Dari hasil penelitian dan pembahasan yang telah disampaikan, dapat disimpulkan bahwa beban kerja yang tinggi dan berlebihan menyebabkan penurunan pada Kepuasan Kerja Perawat Rumah Sakit Unipdu Medika Jombang. Beban kerja yang tinggi dan berlebihan juga menyebabkan peningkatan stress kerja perawat dan stress kerja yang tinggi menyebabkan penurunan pada kepuasan kerja perawat. Stress kerja memediasi pengaruh antara beban kerja terhadap kepuasan kerja perawat sehingga dapat diartikan apabila terjadi peningkatan beban kerja pada perawat, akan meningkatkan pula stress kerjanya, dengan meningkatnya stress kerja mereka, terjadilah penurunan kepuasan kerja secara signifikan.

Maka dari simpulan tersebut diatas, disarankan kepada pihak rumah sakit perlu memperhatikan beban kerja perawat yang tinggi, terutama standar waktu pelaksanaan kerja, waktu istirahat, jumlah pekerjaan, tingkat kesulitan pekerjaan dan tingkat resiko pekerjaan. Pihak rumah sakit perlu memperhatikan stress kerja perawat yang tinggi, terutama pada indikator sering mudah marah, sering mengalami kelelahan fisik, sering pusing kepala, dan mengalami gangguan tidur. Manajemn rumah sakit sebaiknya memberikan pengarahan terutama pada pelayanan yang perawat berikan, hal ini akan mempengaruhi kepuasan pasien, mengadakan family gathering, serta diharapkan dapat mengelola stress kerja tersebut agar tidak sampai tinggi. Selain itu, pihak rumah sakit perlu memperhatikan Kepuasan kerja perawat yang rendah, terutama pada pembayaran/gaji, kesempatan memperoleh promosi jabatan, dan sikap pimpinan. Manajemen rumah sakit hendaknya memberikan gaji sesuai dengan Upah Minimum Kabupaten (UMK) bagi perawat yang sudah menjadi pegawai tetap, mengadakan promosi jabatan, dan selalu mengupayakan agar pimpinan dapat bersikap terbuka dan ramah terhadap semua karyawan. Hal ini dilakukan untuk meningkatkan kepuasan kerja karyawan, meningkatkan kesejahteraan dan komitmen terhadap perusahaan.

Untuk penelitian selanjutnya dapat menambahkan variabel lain kedalam penelitian ini seperti kompensasi, disiplin kerja, lingkungan kerja, K3 (kesehatan dan keselamatan kerja), kinerja atau variabel lainnya dengan menggunakan objek yang berbeda sehingga hasil penelitian jadi lebih baik.

\section{DAFTAR PUSTAKA}

Ahmadun, Muhammad dan Syaifudin. 2017. Hubungan Beban Kerja Perawat Dengan Stress Kerja Di Puskesmas Kuala Kampar Kabupaten Pelalawan Provinsi Riau. Jurnal Ilmu Keperawatan Universitas Aisyiyah Yogyakarta.

Alhasanah, Nuril Hidayah. 2016. Gambaran Kinerja Perawat Berdasarkan Beban Kerja di Instalasi Rawat Inap Penyakit Dalam Rumah Sakit Umum (RSU) Kota Tangerang Selatan. Skripsi Manajemen Pelayanan Kesehatan. Universitas Islam Negeri Syarif Hidayatullah Jakarta. 
Ambarwati, Diah. 2014. Pengaruh Beban Kerja Terhadap Stress Kerja Perawat IGD Dengan Dukungan Sosial Sebagai Variabel Moderating Pada RSUP Dr. Kariadi Semarang. Skripsi Universitas Diponegoro Semarang.

Amelia, Reza. 2013. Pengaruh Budaya Organisasi dan Stress Kerja Terhadap Kinerja Karyawan Melalui Kepuasan Kerja Sebagai Variabel Intervening Karyawan Bank Mandiri Cabang Padang. Jurnal Manajemen Universitas Andalas Padang. Anggraeni, Karina. 2018. Analisis Pengaruh Beban Kerja Terhadap Kepuasan Kerja Dengan Stress Kerja Sebagai Variabel Intervening Pada Karyawan CV. Bartec Utama Mandiri Semarang. Jurnal Ekonomi dan Bisnis Universitas Diponegoro.

Baron, R.M dan Kenny, D.A. 1986. The Moderator-Mediator Variable Distinction in Social Psychological Research : Conceptual, Strategic, and Statistical Considerations. Journal of Personality and Social Psychology. Vol. 51. No.6. pp 1173-1182.

Bey, M. T., \& Dewi, R. C. K. (2018). Pengaruh Budaya Organisasi Dan Komitmen Organisasi Terhadap Kinerja Karyawan Pada BPJS Ketenagakerjaan Kantor Cabang Jombang. JMD: Jurnal Riset Manajemen \& Bisnis Dewantara, 1(1), 3748.

Chuzaeni, Faisal. 2017. Pengaruh Beban Kerja Terhadap Kepuasan Kerja Melalui Stress Kerja Pada Perawat Rumah Sakit Lavalette Malang. Jurnal Manajemen Universitas Negeri Malang.

Dhania, Dhini Rama. 2010. Pengaruh Stress Kerja, Beban Kerja Terhadap Kepuasan Kerja Pada Medical Representatif Di Kota Kudus. Jurnal Psikologi Universitas Muria Kudus. Vol I, No. 1.

Febriani, Diana. 2017. Pengaruh Beban Kerja dan Gaya Kepemimpinan Terhadap Kinerja Karyawan Pada Bank BCA KCP Golden Trade Center Medan. Skripsi. Universitas Sumatera Utara Medan.

Ghozali, Imam. 2009. Aplikasi Multivariate dengan Program SPSS. Semarang : Badan Penerbit Universitas Diponegoro.

Ghozali, Imam. 2011. Analisis Multivariate SPSS. Semarang : Badan Penerbit Universitas Diponegoro.

Handoko, T Hani. 2008. Manajemen Personalia dan Sumber Daya Manusia Edisi Kedua. Yogyakarta : BPFE Yogyakarta.

Hannani, Ahmad, dkk. 2016. Pengaruh Beban Kerja, Kepuasan, dan Fasilitas Terhadap Kinerja Perawat di Ruang Perawatan Mawar Lantai II RSU Wisata UIT Makassar. Jurnal Mirai Manajemen. Vol 1, No.2.

Mahfudz, Muhammad. 2017. Pengaruh Kepuasan Kerja dan Beban Kerja Terhadap Kinerja Karyawan dan Stress Kerja Sebagai Variabel Mediasi Pada Karyawan Divisi Sales Consumer PT. Bank Negara Indonesia (Persero) Tbk. Jurnal Eksekutif Manajemen Universitas Pancasila. Vol 14, No.1.

Mangkunegara, Anwar Prabu. 2017. Manajemen Sumber Daya Manusia Perusahaan. Bandung : PT. Remaja Rosdakarya 
Marsono. 2016. Metode Penelitian Kuantitatif. Bogor : IN MEDIA

Munyati, Eka Amalina, dkk. 2017. Pengaruh Beban Kerja Terhadap Kepuasan Kerja dan Stres Kerja Karyawan Bagian Maintenance PT. Semen Bosowa. Jurnal Universitas Hassanudin Makassar.

Nimran, Umar dan Amirullah. 2015. Manajemen Sumber Daya Manusia dan Perilaku Organisasi (Pendekatan Riset). Malang : Sinar Akademika Malang

Noor, Juliansyah. 2016. Metodologi Penelitian. Jakarta : PRENAMEDIA GROUP.

Nurali, N. (2018). Pengaruh Insentif Terhadap Kinerja Karyawan Yang Dimediasi Motivasi Kerja Karyawan Pada PT Sedulur Guyub Rukun Pandanwangi Jombang. JMD: Jurnal Riset Manajemen \& Bisnis Dewantara, 1(1), 13-24.

Nurcahyati, Bibit. 2014. Pengaruh Beban Kerja Terhadap Stress Kerja Perawat IGD RSUD A Wahab Sjahrani. Jurnal Psikologi Universitas 17 Agustus Samarinda.

Peraturan Menteri Dalam Negeri No. 12 Tahun 2008. Analisis Beban Kerja di Departemen Kementrian dan Pemerintah Daerah.

Priansa, Donni Juni. 2017. Perilaku Organisasi Bisnis. Bandung : Penerbit Alfabeta.

Rivai, Veithzal dan Ella Jauvani Sagala. 2009. Manajemen Sumber Daya Manusia Untuk Perusahaan Edisi Dua. Jakarta : PT. Raja Grafindo Persada.

Robbins, Stephen P. 2007. Perilaku Organisasi. Jakarta : PT. Macanan Jaya Cemerlang.

Saefullah, Encep, dkk. 2017. Pengaruh Beban Kerja dan Stress Kerja Terhadap Produktivitas Kerja Karyawan PT. Venia Agape Indonesia. Jurnal Akademika STIE Bina Bangsa Banten. Vol 15, No. 2.

Sarwendah, Endah. 2013. Hubungan Beban Kerja dengan Tingkat Stress Kerja Pada Pekerja Sosial Caregiver di Panti Sosial Tresna Werdha Budi Mulia DKI Jakarta. Skripsi Ilmu Keperawatan Universitas Islam Negeri Syarif Hidayatullah Jakarta.

Siagian, Sondang P. 2008. Manajemen Sumber Daya Manusia. Jakarta : PT. Bumi Aksara.

Siagian, Sondang P. 2016. Manajemen Sumber Daya Manusia Edisi Satu. Jakarta : PT. Bumi Aksara.

Sobirin, Achmad dan Khairi Setiawan Sejati. 2015. Pengaruh Stress Kerja dan Lingkungan Kerja Terhadap Kinerja Karyawan yang Dimediasi Oleh Kepuasan Kerja di PT. Madubaru Yogyakarta. Diakses Tanggal 13 Maret 2018. Jurnal Manajemen Universitas Diponegoro.

Sugiyono. 2013. Metode Penelitian Bisnis. Bandung : CV. Alfabeta

Susanti, Nelfiandra. 2015. Pengaruh Karakteristik Individu dan Beban Kerja Guru Terhadap Kepuasan Kerja Dengan Stress Kerja Sebagai Variabel Intervening Pada Guru SDN di Kecamatan Pasaman Kabupaten Pasaman Barat. Jurnal Manejemen Pascasarjana Universitas Bung Hatta. 
Sutarni, Nani. 2008. Hubungan Beban Kerja Dengan Kepuasan Kerja Perawat Pelaksana di Instalasi Rawat Inap Rumah Sakit Kanker Dharmais Jakarta. Tesis Ilmu Keperawatan Universitas Indonesia.

Umam, Khaerul. 2010. Perilaku Organisasi. Bandung : Pustaka Setia

Wijaya, Andri. 2018. Pengaruh Beban Kerja Terhadap Kepuasan Kerja Dengan Stress Kerja Sebagai Variabel Mediasi Pada Pekerja di Hotel Maxone Kota Malang. Jurnal Parsimonia Universitas Ma Chung Malang. Vol 4, No. 3.

Yo, Putu Melati Purboningrat dan Ida Bagus Ketut Surya, 2015. Pengaruh Beban Kerja Terhadap Kepuasan Kerja Dengan Stress Kerja Sebagai Variabel Mediasi di PT. Lianinti Abadi Denpasar. Jurnal Manajemen Universitas Udayana. Vol 4 No. 5. 